T. N. Mikayılov', A. A. Bayramov ${ }^{2}$

${ }^{1}$ Ministry of Defence of the Azerbaijan Republic, Baku, Azerbaijan

${ }^{2}$ War College of Armed Forces of the Azerbaijan Republic, Baku, Azerbaijan

\title{
THE POSSIBILITY OF CREATING AN AUTOMATED CONTROL SYSTEM OF THE VARIOUS MILITARY GROUPS
}

\begin{abstract}
From the experience of war and armed conflicts that have taken place in recent times, it seems that the exchange of information in all the fields of warfare is very important in the military confrontation, which are conducted traditionally and basically using new methods of struggle. Given importance of this factor, leading states have increased their efforts to create a network command and control system of combat operations by utilizing new information technologies. Nowadays, automation of the command and control systems is an effective way of carrying out of military operations (combat operations), covering the Armed Forces command and control system from the operators of the arms systems to the top command. In this paper there have been analyzed the possibilities for data processing and its management of the Armed Forces and Weapons in the Automated Control System (ACS). To create conditions for coordinated actions between types of Army, the possibility of transform their response zones into a coordinated battlefield has been disclosed. During the decision-making process, it has been shown that the process of data collection, analysis and distribution is the most effective technological tool for modeling of operation.
\end{abstract}

Keywords: army; fire destructions means; automated control system; special software; military conflict; automation complex.

\section{Introduction}

The modern combined arms operations (battle) is characterized by high dynamism of combat conditions, maneuverability of troops, large spatial coverage, lack of precise contact line and high degree of independence of troops. The key to achieving goals is the ability to have superiority on control the enemy, intelligence, destructive fire, communication, radioelectronic fighting and navigational systems [1]. Increasing the efficiency of these is directly dependent on resolving the contradictions between the high maneuverability of troops with low maneuverability of the command and control points in the combat field and the weakness on enemy's striking fire and the effects of radio electronic suppression. The solution of this issue is possible by the creation and implementation of automated command and control systems in the armed forces using modern information technologies.

From the experience of war and armed conflicts that have taken place in recent times, it seems that the exchange of information in all the fields of warfare is very important in the military confrontation, which are conducted traditionally and using new methods of struggle. Given the importance of this factor, leading states have increased their efforts to create a network command and control system of combat operations by utilizing new information technologies.

Nowadays, automation of the command and control systems is an effective way of carrying out of military operations (combat operations), covering the Armed Forces command and control system from the operators of the arms systems to the top command.

The main purpose of the automation of command and control system is to increase the efficiency of the use of potential capabilities of the troops and combat means of destructions. The automated management system carries out information technology for performing certain functions consisting of staff and its automation tools.

One of the ways to increase the effectiveness of the use of troops and means of destructions is to predict the outcome and consequences of military operations by using mathematical modeling. The purpose of the application of modeling technologies is simultaneously reduce material and financial costs by increasing the effectiveness of the use of military forces and combat means of destructions [2].

Changes in the structure and logistic support of the Armed Forces, changes of the management in peacetime and wartime, and changes in the forms and methods of using various military units in the military operations encourage the improvement of operationaltactical calculation methods, the creation of specialized mathematics and software for military purposes.

However, it can be concluded that practical implementation of these concepts is possible with the utilization of new information technologies and maximum automation of the management system in the process of command and control the troops and combat means of destructions. Implementation of these provisions will be achieved through complex automation of troops command and control processes and establishment of a highly automated, stationary, mobile battle command-control system, which operates in real time as close as it possible does.

\section{Approach to the creation of an automated management system}

The maximum automation, operative and justification of the headquarters, which ensures the level of effectiveness of the tasks of headquarters, should organize the basis for the creation of the automated control system of armies and combat means 
of destructions. This is possible through extensive automation of main processes of the command and control systems at all levels in the automated command and control system of troops.

The analysis of the work carried out in the field of automation of command and control systems and application of information technologies in decisionmaking practice shows that the up-to-date investigations covered mainly automation questions for the management of separate functional systems. At the same time, it is evident from research and practice that the effectiveness of command and control is reduced when automation is not associated with the objectives and tasks of the combined troops operation [battle] [3].

Therefore, the systematic approach to automation should be focused on the command and control theory.

The functional activities of officials should be taken into consideration and mathematical models should be used during the process of the automation of headquarters work practice and the application of new information technologies.

At this time, the design of the automation system should define its:

system principles, structure, functions and subsystems;

locations of information resources;

principles and protocols of exchange;

requirements for type of assurance and interface requirements.

Analysis of military command and control technologies and application of information technologies allows selecting a number of priority areas during work on automation of troops and weapons management systems.

The first, in the face of modern armed conflicts, the sides which has quickly explore information about the composition, position and nature of the opposite grouping and had transmit this, in accordance with the circumstances, makes the decision, conducts planning and achieves the advantage over the enemy by implementing its intentions.

The advantage of information allows the achievement of the objectives set out in the case of less labor and combat means of destructions than the enemy one.

This can be achieved primarily by the creation of a unified information command and control system for automation of management, communications, intelligence and automation of the radio-electronic systems and on that basis their automated management of troops from the destructive weapon level to the strategic headquarters.

Secondly, there are always changes in the means and methods of the armed struggle, but modern and perspective operations are of a general character. It appears from the experience of modern war and armed conflicts, the concept of air-to-surface operations. Therefore, automation is based on general operations. Establishing an automated command and control system for troops and combat means of destructions an integrated approach to integrating the functional subsystem of forces and types of troops into a single managed system based on common principles and rules. Its main components should be the automated sub-systems of land forces, air force and air defense armies, intelligence, communications, radio-electronic warfare, technical and logistics [4].

Third, the increasing complexity of the military operations management processes of different types of troops requires increasing the intellectual level of the automation tools. It is extremely difficult to make a decision on the conditions that arise from systematization of the information flow, even if the process of collecting, processing and reflection of incoming information is automated.

The application of electronic computing techniques in automation equipment complexes creates conditions for increasing the quality of information processing and efficient management of its issues. Where there is no effective intellectual approach, this is simply a simple reference-information system with the ability to solve individual computing issues.

Therefore, it is necessary to include a complex of multifunctional mathematical models that reflect the real conditions of combat operations, taking into account the functioning of the troops of the automation equipment complexes to be developed in the future [5].

According to military experts from the leading states, mathematical models allow to unite the various types of information flows in the military administration in a single system and to create a base for better introduce to commander about combat condition.

Modeling the development of the different options can provide effective support for decisionmaking. This approach provides for the application of a mathematical modeling complex for immediate control of the troops (combat vehicles) during the execution of combat missions, taking into account the fact that the simulation of combat activities is often faster than real.

In this case, information about specific operational and combat conditions can be used to select targeted managerial activities that enable the modeling of various development variants of combat activities and the achievement of their goals.

Based on the priorities mentioned, the following approach can be used to establish an automated command and control system for troops and combat means of destructions:

- The ACS structure should incorporate all officials, including communication, intelligence, combat means of destructions and radio-electronic control systems into a single information management network;

- ACS to be built on the principle of modules should be able to develop flexibly and continuously based on a single information management network; 
- Integrated standards and formats should be used here, full compliance should be ensured, including software and hardware used and unauthorized access to information;

- The basis of the ACS should be provided with a vertical and horizontal link that provides an effective, realistic function, prompt access to information verified by any officials should be ensured;

- The decision-making support system implemented in the ACS, the planning of the deployment of troops and combat means of destruction should be based on complex multifunctional mathematical models and modern Custom Mathematics and Software (CMS). At this time, the following model groups should be included in the CMS:

- a model of systems and combat means of military appointment, which also reflects the properties of weapons and combat technology;

- models of troops that describe the activities of different military units, their strengths and types of troops, due to their authority;

- communication systems and management systems of troops and its groups;

- assessment models of the methods of the troops' use;

- models of combat activities reflecting physical and geographical features and infrastructure elements;

- models of daily operations processes and facilities of troops.

Practical implementation of the views mentioned above allows to create the centralized network-based and regional-type ACS network distribution that ensures command and control of troops and combat means of destructions from central command point. The modular installation of the system is conditioned by the compatibility of information processes conducted at all levels of headquarters (commanding officials) at this time. Technical basis of the modules that provide functionality of the officials should be made up of universal automated work places combined in the local computing network of the command and control points [6].

The size and number of management tasks, as well as the number of modules in the automation sector, military officials and troops management system depending on the location of the event is determined as a function by the specific control group.

\section{The application of automation systems}

The basis for the logical-information combination of computing means for data compilation should be a general CMS based on the module principle.

It should ensure that the efficient work of the military officials in the daily activities on the preparation and combat operations of the troops.

New information technologies, expert systems, collective work with artificial intelligence in its development systems and military geo-information systems should be create, as well as a complex of mathematical models capable of providing management solutions. Therefore, one of the important directions of the establishment of ACS for troops and combat means of destructions is the development of the CMS.

The military units should provide the following when establishing ACS:

- Adaptation of the structure, composition and interaction of system elements to the conditions of the troops;

- High durability in the conditions of active fire and radio-electronic impact of the enemy;

- comprehensive substantiation of the decisions made, automation of operational-tactical calculations, preparation of graphical documents with the execution of tasks, and prompt delivery of battle commands and signals.

Implementation of these requirements is possible in the ACS, which is based on the distribution of data in local computing networks. The composition and functionality of the ACS elements allows it to adapt to real conditions without organizational and technical changes. Therefore, the system must have a modular structure, and the supply of each module with automation means must conform to the level of the management system [7].

It should be noted that their practical realization is impossible without the development of a unified territorial communications system. This perspective envisages the establishment of a unified telecommunication network based on information technology and the use of channels and automation tools for modern digital communications. For this matter, development of perspective network protocols able to perform dynamic addressing and modular networks management tasks is required. Communications systems on tactical level should be develop on the way of multifunctional datamanagement system of the system development, built on the base of integrating management functions of troops, combat means of destruction, intelligence and means of radio-electronics struggle.

This system should be coordinated with the ACS operational level and distributed in the field of warfare and composed of appropriate automation tools and management modules integrated into a single system of mobile communication systems.

The complex of automation means should be created in accordance with the principles of unification, modulation, architecture, and adaptation. At this time, installation of module based on principles of the systems network must ensure the complex of activities of the management system of the units and the automation of the signals and command of battle management control.

The basis of the ACS should be a set of automation tools equipped with software and hardware at all levels of commanding position, from the unit commander to the staff. 
Interconnection between all complexes of automation means, automated workplace, mobile and stationary command and control points, also movable automation means of commanders at tactical level, performs by navigation-communication terminals.

The software of the automation toolkit must be authenticated, and the level of subordination should be determined by its regulation. This allows the automation tool complex of any management level to be adapted to the organizational structure changes of the troops. In addition, the principle of integrated software for the complexes of automation means should be applied (the same software package is installed in the automated workplace of each official). Access to information and assignments should be achieved by adjusting the protection of system's settings against unauthorized access [8].

In the ACS, the information circulation should be carried out in real time and transmitted in the form of a graphical, text, table and video description, which is optimal for perception. This allows the unit commander to be fully informed about his units activities in the battlefield.

\section{Directions of use of information technologies in the processes of the troops management}

The proposed approach allows all military officials to obtain any information that is related to them and to use them in the interest of maximizing the combat capabilities of subordinate divisions and units. At this time, every part of the system is becoming a supplier of information, as well as to be demanding. However, if these conditions are met, the system may operate without interruption by the opposite effect of the enemy`s information activity.

Practical implementation of the establishment of ACS of troops and combat means of destruction into the work practice of the military administration, automation systems and troops management processes is impossible without the creation of a System of Information Technology Introduction. The capabilities of information technology and automation tools should be fully explored by officials to ensure more effective functioning of the system.

From the analysis and experience in the field of automation toolkit in automation sphere and CMS has shown that there are a number of problems with the development and implementation of multifunctional mathematical models, algorithms and specific software packages.

The solution to these problems is only possible through professional research. At this point, special attention should be given to the modeling of operations and combat activities
Here, there is a need to resolve the scale of large tasks to determine the scope from the development of the mathematical and imitation models of the armed struggle and the developing directions of the CMS development programs, to their practical implementation [9].

It is therefore more appropriate to solve the following tasks:

- the creation of a multifunctional mathematical model complex of different levels of operation and combat activities and simulation of the bilateral imitation of armed struggle;

- creation CMS of the automation tool system and their next development, its scientific-methodical, methodological and technological compatibility;

- development of the calculation and information programs of the combat operations and planning tasks for the destructive strikes and ACS basic information provision;

- formation of scientific-methodical apparatus for system design of software packages of local computing network on the basis of modern information technologies.

These operations provide a scientific approach to mathematical programming, research and modeling of combat activities, as well as mathematical maintenance of ACS automation tools.

Overall, special attention must be paid to the issue of establishing an ACS database in the troops and combat means of destruction based on unified and standardized software with technical and information support.

\section{Conclusion}

So, the approach to the proposed ACS allows the systematic development of a complex of automation tools aimed to accomplish a specific management tasks and the needs of the functional groups and military commanding officials in a single system.

So that:

1. The use of mathematical modeling methods in the creation of an automated management system enhances the effective use of different groups of troops in the combined arms operations.

2. The development of special software creates conditions for units and troops to carry out their military tasks according to prediction of the course and result of the operation and depending on situation by supporting decision-make process to use troops.

3. The modular construction of the automation tool complex in the Automated Control System ensures compliance with the information and management processes carried out in the command and control department.

\section{REFERENCES}

1. Mikayilov, T.N. and Bayramov, A.A.(2018), "Impact of Fire Management System on Targets Impact Effectiveness", Military Review, vol. 3 (01), pp. 28-32.

2. Mikayilov, T.N. and Bayramov, A.A. (2019), "The factors of enemy destruction fire in the single information space during combat operations", Journal of Defense Resources Management, Bucharest, vol. 10, is. 1(18), pp. 121-130. 
3. Lyapin, B.P. and Barvinenko, V.V. (2015), "Unified information-modeling environment in military systems", Military Thought, No. 4, pp. 72-78.

4. Denisov, V.N., Sayapin, O.V. and Tikhanichev, O.V. (2016), "About the place of mathematics modeling in the work of military authorities", Military Thought, No. 5, pp. 28-33.

5. Barvinenko, V.V. (1999), "On the automation of the management of groups of the Armed Forces", Military Thought, No. 2, pp. 12-28.

6. Vypasnyak, V.I., Tikhanychev, O.V., Bazunov, S.R. and Rubtsov, K.V. (2019), Information and analytical planning system for fire destruction of the enemy group, available at: http://poleznayamodel.ru.

7. Joint Publication 3-09 Joint Fire Support (2002), Department of the Army, Washington, DC, available at: https://fas.org/irp/doddir/dod/jp3_09.pdf.

8. Information technology (2019), available at:: https://ru.wikipedia.org.

9. Skantsev, A. (2019), On the issue of the automating control system of US Armed Forces, available at: http://pentagonus.ru/.

Надійшла (received) 30.05.2019

Прийнята до друку (accepted for publication) 24.07.2019

\section{Відомості ПРО АвторIв / АвоUT тHE AUTHORS}

Микаилов Телман Неман оглы - доцент, полковник, Міністерство Оборони Азербайджанської Республіки, Баку, Азербайджан;

Telman Neman oğlu Mikayilov - assistant-professor, colonel, Ministry of Defense of the Azerbaijan Republic, Baku, Azerbaijan;

e-mail: telman.mikayilov@yahoo.com; ORCID ID: https://orcid.org/0000-0003-2608-7813

Байрамов Азад Агалар оглы- доктор фізико-математичних наук, професор, професор-консультант, Військова Академія Збройних Сил Азербайджанської Республіки, Баку, Азербайджан;

Azad Agalar oğlu Bayramov - Doctor of Physics and Mathematics, Professor, Professor-consultant, National War College of Armed Forces of the Azerbaijan Republic, Baku, Azerbaijan;

e-mail: azad.bayramov@yahoo.com; ORCID ID: https://orcid.org/0000-0001-6672-2338

\section{О возможности создания \\ автоматизированных систем управления различных воинских частей}

Т. Н. Микаилов, А. А. Байрамов

Аннотация. Из опыта войн и вооруженных конфликтов, имевших место в последнее время, представляется, что обмен информацией во всех сферах военных действий очень важен в военном противостоянии, которое традиционно и в основном проводится с использованием новых методов борьбы. Учитывая важность этого фактора, ведущие государства активизировали свои усилия по созданию сетевой системы управления боевыми действиями с использованием новых информационных технологий. В настоящее время автоматизация систем командования и управления является эффективным способом проведения военных действий (боевых действий), охватывающих систему управления вооруженными силами от операторов систем вооружения до высшего командования. В данной статье были проанализированы возможности обработки данных и управление вооруженными силами и оружием с использованием АСУ. Для создания условий для согласованных действий между различными подразделениями была раскрыта возможность превращения их зон реагирования в скоординированное поле битвы. В процессе принятия решения было показано, что процесс сбора, анализа и распространения данных является наиболее эффективным технологическим инструментом для моделирования работы.

Ключевые слова: армия; средства огневого поражения; автоматизированная система управления; специальное программное обеспечение; военный конфликт; автоматизированный комплекс.

\section{Про можливість створення автоматизованих систем управління різних військових частин \\ Т. Н. Мікаілов, А. А. Байрамов}

Анотація. 3 досвіду воєн і збройних конфліктів, що мали місце останнім часом, здається, що обмін інформацією в усіх сферах військових дій дуже важливий у військовому протистоянні, яке традиційно і в основному проводиться 3 використанням нових методів боротьби. 3 огляду на важливість цього чинника, провідні держави активізували свої зусилля зі створення мережевої системи управління бойовими діями з використанням нових інформаційних технологій. В даний час автоматизація систем командування і управління $є$ ефективним способом проведення військових дій (бойових дій), що охоплюють систему управління збройними силами від операторів систем озброєння до вищого командування. У даній статті були проаналізовані можливості обробки даних і управління збройними силами і зброєю 3 використанням АСУ. Для створення умов для узгоджених дій між різними підрозділами була розкрита можливість перетворення їх зон реагування в скоординоване поле битви. У процесі прийняття рішення було показано, що процес збору, аналізу та поширення даних $€$ найбільш ефективним технологічним інструментом для моделювання роботи.

Ключові слова: армія; засоби вогневого ураження; автоматизована система управління; спеціальне програмне забезпечення; військовий конфлікт; автоматизований комплекс. 